\author{
Nicholas PrimacheV \\ ORCID https://orcid.org/0000-0003-0192-2894 \\ TATYANA FRASYNYUK \\ ORCID https://orcid.org/0000-0003-3458-3796 \\ National University "Odessa Maritime Academy"
}

\title{
UKRAINE: AN EXAMPLE OF LIMITS OF BALANCE AND ASYMMETRIC REACTION IN THE MARITIME TRADE MARKET
}

KEYWORDS: shipping companies, balance, normalization of parameters, positioning stability, Ukraine

AвSTRACT: This article deals with the principles of reaction of shipowners' structures on the set of changes in the maritime trade market's parameters. There are features of decision-making within the uncertain variability of the maritime trade market. Thus there are subsystems clearly realizing prioritizing strategies, and subsystems that choose the form of reaction to changes in the conditions of limited resources in the structure of the global maritime transport industry. Maintaining a balance, as the most effective condition of any market, plays a special role in maritime transport due to the high cost of fleet deadweight and the intensity of the crews' work. Therefore, the clarity and timeliness of the response to external changes in traffic flows and carrying capacity of competing shipping companies becomes paramount.

\section{Introduction}

The assessment of uncertainty behavior in the medium of freight traffic formation is a characteristic feature of a shipping company's positioning as a business structure. It should be noted that during a normalized lifecycle, phases of formation, flowering and the loss of potential competitiveness may alternate in a random order. In these circumstances, the desire of shipowners for the most rapid increase in transport capacity and profits is formed during the active state of the freight market. This is what determines the formation of periods of unbalanced state in the maritime trade market.

Under these conditions the institutional mechanisms for regulatiio of merchant shipping are gradually formed (Kotlubay 2011).The problem is the allocation of economic and legal regulators of justice and security for transport fleet development.Special attention is paid to controlling the activities of substandard shipping companies, as a factor of an asymmetric response to the current operating conditions of the maritime trade market.A subject of such regulation is the working and living conditions of seafarers on board. 
Three objectives - to achieve financial stability, efficient use of the transport factor and management of energy security - acquire fundamental significance in contemporary conditions of the globalization of international trade (Primachev 2011). The urgency of solving these problems is due to the initial unequal distribution of raw material and energy resources by regions of production, which determines the role of the transport service reliability.

Therefore, competitive solutions to the same problems are constantly formed. In this regard, it is enough to consider the role of the energy strategy of the European Union and Russia. Attention is focused on providing not only the first problem, but also political goals. Alternative embodiments of energy resource supplies are simultaneously viewed. In this regard, it suffices to mention the "Blue Stream" project of deliveries of Russian gas to Europe via Turkey, bypassing Ukraine. At the same time, Turkey, the United States and Azerbaijan are implementing a gas pipeline project through Turkey to Bulgaria from the Shah Deniz field of similar capacity.

Under these conditions it is important that the formation of an adequate maritime transport policy for Ukraine and the nature of the reaction of business structures to permanent changes should be established.Therefore, the role of task research and selection of the individual stages in the formation of competitive capacity for the national maritime transportation industry is growing.

\section{Literature Review}

The priority for maritime transport development within the system of stable positioning of the national industrial complex in the international labor division is widely covered (Nikolaeva 2008; Primachev 2009; Primachev/Klimek et al. 2014). Therefore, we cannot agree with theoretical justifications for the abandonment of marine transport potential on the basis that there is no cargo base. Unfortunately, for a long period sectoral leadership was not competent in the management of maritime transport. Firstly, the entire global merchant fleet is positioned not on the basis of national freight, but on the marketing technologies of the global freight market. Secondly, the largest capacity of the "Antarctica" fishing fleet has virtually disappeared without the disappearance of the world's fish stocks. And, thirdly, the ability to interact officials and experts in the selection of transmission of state property into private hands, indicates a peculiar professionalism in the new managers.

Under these conditions the nature of the approaches of a number of researchers (Kotlubay 2004; Zhikhareva/Kotlubay/Kibik 2012; Ilchenko 2012; Primacheva/ Senko/Frasinyuk 2015) to the choice of fleet positioning strategy in the constantly changing environment of the fleet's functional activity deserves attention. 


\section{Purpose}

The national merchant fleet is not developing because of the uncertainty of the institutional position of the marine transport industry of Ukraine, and the contradictions between stevedoring companies and the state port control which have formed in the port structure. Under these conditions the competing companies: Constanta, Novorossiysk and Burgas have implemented development projects of $\$ 2.1$ billion. In a normal economic and legal regime not less than half of these investments could be the basis for improvement of the technical and economic level of the port terminals of Ukraine.

At the same time administrative regulation in the context of globalization, on security and environmental criteria has led, to a certain extent, to a weakening of strategies for cost reduction. During the boom of maritime transportation with the growth in freight rates it was imperceptible. However, with a reduction in vessel employment for cargo transportation the high average costs have predetermined financial disaster for a number of shipping companies. It is therefore important to note the preservation of the role of the principle of adequacy of the technical level and competitive prime cost in the development strategy.

In this respect, the main purpose of research is the systematization of conditions to achieve a balanced state of subsystems in the Maritime transport industry on changes in the maritime trade market performance conditions.Special attention is paid to the selection of reaction asymmetry to leadership strategies for prioritizing the leading operators.

\section{Results}

The global transport industry and its separate specialized components (Kotlubay 2011) operate on a basis formed by the standards of conduct in terms of objectivity of economic competition and survival strategies (fig. 1). A system of modes of behavior of separate transport companies or logistics complexes has also formed, resulting in a constantly optimized structure of capital assets, owners and operators. The share of objects with inadequate behavior is reduced on perfect competition market.

Creating a second (international) trade fleet register by individual states takes a special place in the asymmetric reaction to the functioning of the global maritime transport industry. International registers, as a rule, do not fall into the black list, as is the case regarding flags of convenience. Therefore, the risk of unexpected losses is reduced. Fear of an inflow of foreign specialists and its impact on employment in the maritime industry is considered to be the only opposition to the establishment of a second register. 


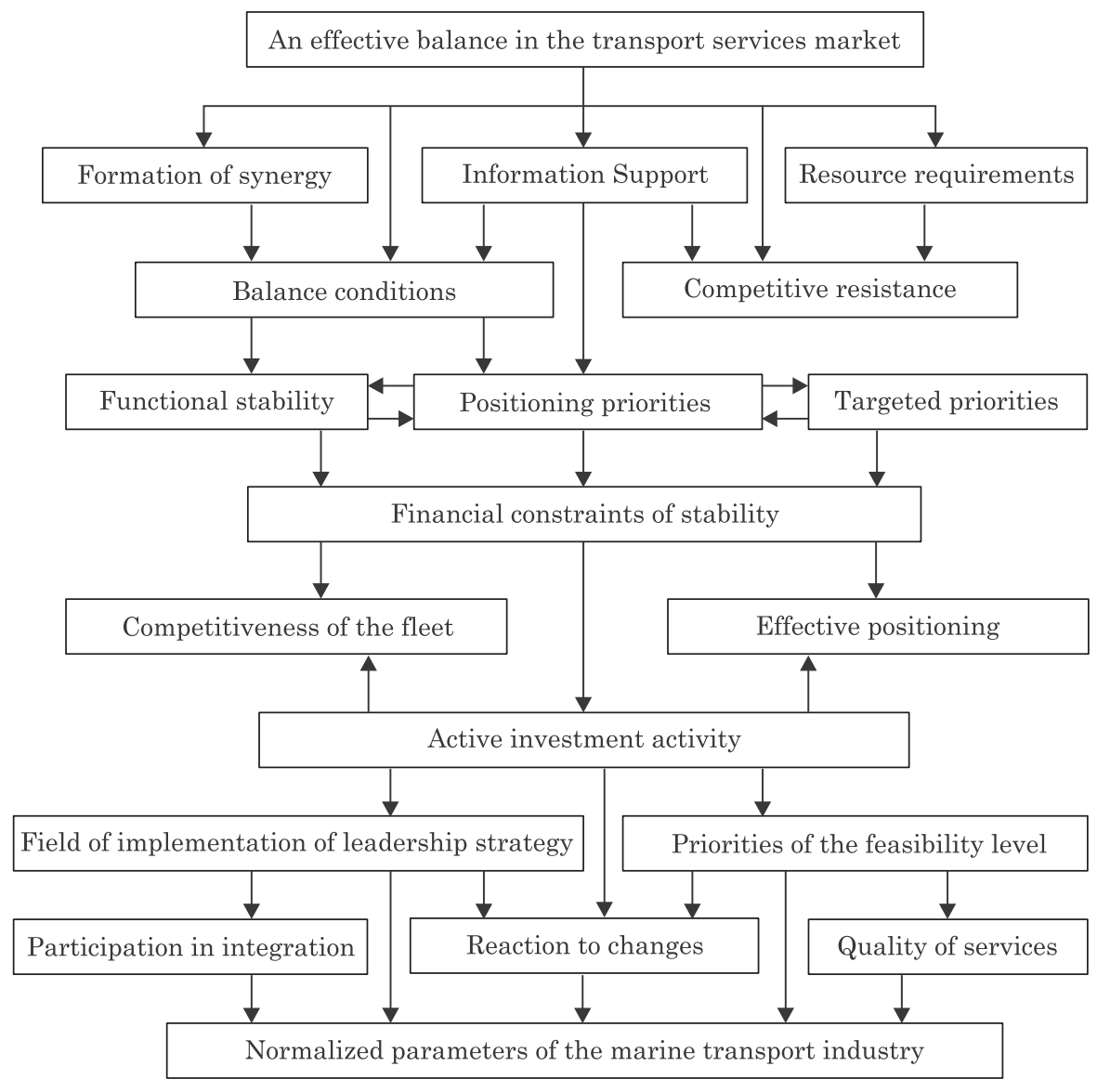

Figure 1. Principles and conditions of management of sustainable marine transport enterprise development Source: developed by authors

From the standpoint of rational economic activity all services should be reimbursed by an appropriate cash flow. In this condition the registration services of the second register are limited to the amount that is sufficient to cover the administrative costs of keeping the register and payment of the relevant employees' work.

It should be noted that the parameters of participation of individual subsystems in the global maritime transport industry are predetermined by a complex set of external conditions and internal fundamental restrictions. The stability of the positioning of the fleet and ports in the global maritime trade market are becoming targets. At the same time an evaluation of possible qualitative changes is essential, and the risk of follow-on economic and investment decisions is associated with this.

Not only the nature of competition in the international labor division among the conditions for sustainable development and positioning of the productive capacity 
of subsystems of the maritime transportation industry, but also the strengthening of principles of the international regulation of merchant shipping on safety systems and environmental criteria should be emphasized. Therefore, solving the problems of financial sustainability of shipping companies is complicated. Retention of a functional position in the segment of specialized shipping company or Sea Trade Port becomes a major factor, as it may seem questionable from the side. The need for activization of investment activity is the most important condition, together with the factor of separation of shipping companies on the basis of full compliance with the conditions of the current state of the marine trade market.

In this case, the technical and economic competence of fleet of operators determines the nature of its participation in the integration processes. The ability to implement the chosen competitive strategy and to ensure adequate quality of transportation services is paramount. The parameters of the activity of the fleet or ports in servicing freight flows of foreign trade should not be regulated by the administration and agreeing system.It should be remembered that maritime transport companies operate in the open market and the level of tariffs is restricted not only by their own costs, but alternative transportation directions.

The value of effective positioning on innovative benefits amplifies among entrepreneurial criteria in the development of global maritime trade market subsystems. It has been emphasized by the tendency to accelerate the use of container carriers' since 2014. The increase in use compared to the previous year was $27 \%$ and reached 50 thousand TEU.The average age of container carriers that were sent for scrap in 2014 was 21.Subsequently, container ships have been sent for scrapping before the expiry of the normative life cycle. This means that the process of reducing the age at which vessels are scrapped becomes a regularity. Against this background, we should note the increase in production capacity of new container carriers at a higher rate than the formation of cargo flows. Such an asymmetry of decisions adversely affects the development opportunities of the fleet of such countries as Ukraine.

At the same time it is necessary to focus on the most important factors of maritime trade market development, among which are: 1) the current state and prospects of development of the international labor division; 2) the degree of freedom and conventional regulation on the basis of merchant shipping standards; 3) the level of business efficiency of shipping companies and trading ports; 4) the state of competition in the management system of the technical and economic level of the fleet and freight terminals; 5) the cyclical nature of the price performance in the segment of production factors and operator activity.

In the world of the seaborne trade industry a concentrated wave of accumulation and renewal of fixed capital of shipping companies started in the period of activation of global economic growth in 2004-2008 (table 1). 
Table 1. Developments in international seaborne trade and world fleet, selected years

\begin{tabular}{|c|c|c|c|}
\hline Years & $\begin{array}{c}\text { International seaborne trade, } \\
\text { selected years } \\
\text { (Millions of tons loaded) }\end{array}$ & $\begin{array}{c}\text { World merchant fleet } \\
\text { (Millions of tons Dwt) }\end{array}$ & Productivity of 1 ton Dwt \\
\hline \hline 2000 & 5984 & 798 & 7.5 \\
\hline 2005 & 7109 & 896 & 8.02 \\
\hline 2006 & 7700 & 960 & 7.7 \\
\hline 2007 & 8034 & 1043 & 7.36 \\
\hline 2008 & 8229 & 1118 & 6.59 \\
\hline 2009 & 7858 & 1192 & 6.59 \\
\hline 2010 & 8409 & 1276 & 6.27 \\
\hline 2011 & 8748 & 1396 & 5.99 \\
\hline 2012 & 9197 & 1534 & 5.85 \\
\hline 2013 & 9514 & 1625 & 5.82 \\
\hline 2014 & 9843 & 1691 & 5.75 \\
\hline 2015 & 10047 & 1745 & \\
\hline
\end{tabular}

Source: Developed by the author using the ideas of publications by UNCTAD 2000-2015

In this case, a strategy of extensive expansion of China's merchant fleet actually should be considered as a new phenomenon. If the "traditional maritime powers" strategies provided the expansion of positions on freight flows, then ensuring transport independence of residents' participation in the international labor division lay at the heart of China's position. This means that the fleet, despite the scale, does not apply to the main regulators of the balance of payments active state. Image component of the national flag's fleet acquires fundamental importance.

Thus, in spite of the significant resistance of global trade turnover parameters (fig. 2), there is not only a slowdown in productivity growth in the fleet, but also its downfall, since 2006. This is due to the asymmetry of the reaction of the individual segments of the merchant fleet to the tightening of system security standards

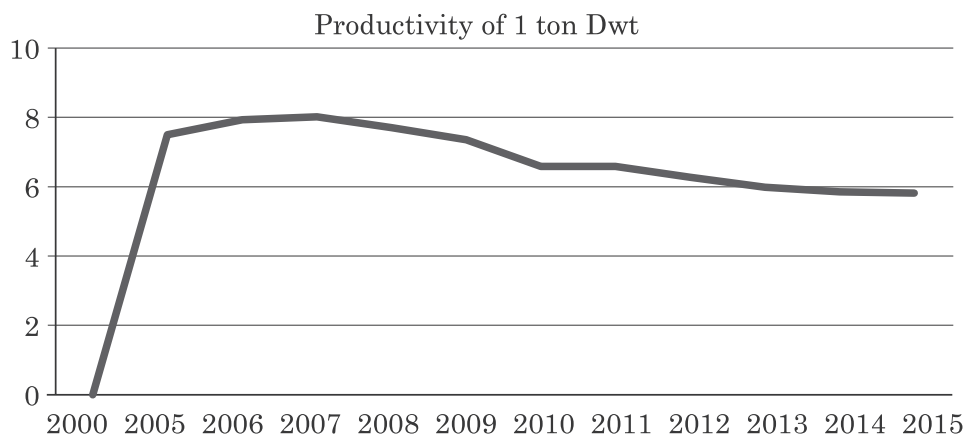

Figure 2. Formation of global maritime trade market asymmetry Source: Developed by author 
on the one hand, and the concentration of investment activity in certain sectors of maritime transport on the priority scale of the economy, on the other.

Net income is of fundamental importance in the management system of macroeconomic growth and enterprise structures. Peculiarities of functioning of the maritime trade market and the international labor division, in accordance with the basic laws of the market, determine the balance and the differentiation of products and services at the pricing level (Vinnikov 2005). The demand and orientation of it's productive capacity restrict the price component in a system of high efficiency. The perceived value of margin assessment by consumers of utility services has a major impact on the diversity of approaches to the management of the net result. Rational use of the resource potential must generate a sustainable ratio in the growth rate of production and economic results of the fleet due to the growth of productivity.

The main condition for the balanced development of the global maritime transport industry is algebraically presented as follows

$$
\sum e_{n i} k_{u i} D_{v i} \leq \sum Q_{i} l_{i} p_{r i} \leq \sum G_{j} c_{s a t},
$$

Where $e_{n i}$ - rate of return of capital of the shipping company; $k_{u i}$ - the cost of 1 ton deadweight of ships; $D_{v i}$ - deadweight of specialized vessel groups; $Q_{i}-$ volume of transportation of certain types of goods; $l_{i}$ - average transportation distance of these goods; $p_{r i}$ - profit rate of transport unit performance; $G_{j}$ - volume of foreign trade for the respective positions; $C_{s a t}$ - transportation costs for the delivery of goods to the markets for implementation under the terms of efficiency for the manufacturer.

Unfortunately, Ukraine, for the entire period of political independence, ignored the main provisions of the theory of J. M. Keynes on the development of macroeconomics. And from the standpoint of the priority of a socio-political approach, it turned out to be the poorest country in Europe, with, however, an availability of natural resources that exceeds their availability in the EU. With global economic growth of 3 percent, Ukraine, over the past 5 years, has reduced its GDP and foreign trade by $40 \%$. This is why the volume of cargo turnover at the ports is decreasing annually. The production structure of the country does not meet the requirements of transit cargo flows, and this predetermined their significant reduction. In this respect, China's decision to develop a container terminal in Gdansk following the strategy of the "New Silk Road" rather than in the nearest port of Ukraine, is typical.

The export-import operations of Ukrainian residents are 90 percent secured by a foreign merchant fleet. Even in the government's strategy for the development of transport in Ukraine until 2030, there is no clear approach to the formation of a merchant fleet under the Ukrainian flag. The only position where Ukraine 
retains the semblance of a maritime state is in the seafaring labor market, where officers-citizens of the country occupy 5th-6th place. However, students who already have a higher education are being trained in maritime universities, which underlines the lack of confidence of the able-bodied population in the development of the Ukrainian economy, and its ability to provide decent wages.

These examples highlight the need to clearly use the principles of economic development which are implemented in the EU.

\section{Conclusions}

Unfortunately, not all intentions, decisions and projects for the effective use of Ukrainian transit capacity were implemented. This means that the most important part of the national economy did not participate fully in ensuring balanced economic growth.

Classically, profits should be made in a system of balanced competition on the basis of the principle of cost leadership, and should be based on the positioning scale for qualitative parameters predetermining the objective of price increases or tariff rates. Traditionally, this involves increasing productivity within the limits of the law of diminishing returns.

The globalization of economic relations forms a strategic line ahead of the curve of certain macroeconomic structures. At the same time, enterprise systems division, including maritime transport industry, form integration relations, providing both commercial and synergistic results. These units counteract withheld monopolization of the position in the investment market. Always in the interest of the survival of the individual units it is important to avoid a situation which deviates from any forms of cooperation.

The problem in different profitability of the investment programs remains in an economy built on the management of profit and its normative distribution. Therefore modulations (asymmetry) of capital are formed, followed by violation of balance and the fall of market segment stability. Therefore, the principle of rational differentiation and consideration of other results of the humanization of the economy is important.

Fostering of economic growth in the global economy is based on the natural laws of the economy and the system of special tools. As a part of the latter in the mega economic relations there is the use by developed countries of economic assistance to developing countries, on the one hand, and the export of capital from business structures on the criteria of cheapness of resources and market development on the other hand. This technology is predetermined by the? significant differentiation of the level of development of various countries taking into account national 
peculiarities.This is related to features of formation of cargo flows and the shipbuilding segment.

Shipbuilding as one of the components of the maritime industry of the country, usually develops in accordance with the laws of the market, but within a system of certain institutional support from the state. Ukrainian shipbuilding capacity is not used because of its technical inadequacy in relation to current requirements, the duration of the production vessels and limited skill of the workers, which for the period of the industry's collapse have parted on shipbuilding bases in the world.

The versatility of the formation conditions of the target results and potential, providing functional efficiency of maritime transport enterprises, determines the choice of the mechanism and tools of the strategic objectives management. The collection and inconsistency of interests of all participants of economic relations in specific phases of the market situation exacerbate the differentiation of the assessment of the situation based on the criteria of financial stability. Approaches to the sustainable positioning of the individual subsystems of maritime transport are therefore differentiated.

\section{References}

ILCHENKo, S. (2012), Ukraine in the world transport system: prospects for the functioning and development. The National Academy of Sciences of Ukraine, Institute of Market Problems and Economic and Ecological Research. Odessa.

Kotlubay, O. (2004), Economic mechanisms of merchant shipping in Ukraine. Odessa.

Kotlubay, O. (2011), Problems of the theory and practice of development of sea transport of Ukraine. Odessa.

Nikolaeva, L. (2008), The principles of sustainable development of the shipping companies in the global maritime trade market. Odessa.

Primachev, N. (2009), Methods for measuring the efficiency of maritime transport complex. Odessa.

Primachev, N. (2011), Problems of world seaborne trade market balance. Odessa national maritime academy. Odessa.

Primachev, N./KLimek, H. et al. (eds.) (2014), The problems of sustainable development of the global Maritime transport industry's subsystems. Odessa/Gdansk.

Primacheva, N./Senko, E./Frasinyuk, T. (2015) Anticrise management in commercial shipping. Odessa.

Review of Maritime Transport (2011), United Nations, Geneva. URL: http://unctad.org/en/Docs/ rmt2011_en.pdf.

Review of Maritime Transport (2012), United Nations, Geneva. URL: http://unctad.org/en/PublicationsLibrary/rmt2012_en.pdf.

Review of Maritime Transport (2013), United Nations, Geneva. URL: http://unctad.org/en/PublicationsLibrary/rmt2013_en.pdf.

Review of Maritime Transport (2014), United Nations, Geneva. URL: http://unctad.org/en/PublicationsLibrary/rmt2014_en.pdf.

Review of Maritime Transport (2015), United Nations, Geneva. URL: http://unctad.org/en/PublicationsLibrary/rmt2015_en.pdf.

Review of Maritime Transport (2016), United Nations, Geneva. URL: http://unctad.org/en/Docs/ rmt2016_en.pdf.

VinniKov, $\overline{\text { V. }}$ (2005), Problems of the integrated development of sea transport. Odessa.

Zhikhareva, V./KotlubaY, A./Kibik, O. (2012), Economics of Sea Transport. Kharkiv. 
